\title{
Privacy of the Debtor authorities in the Small Debtors Protective Settlement Procedure according to the Saudi Bankruptcy Law 2018
}

\section{DR. MAEN MOHAMMED AMIN ALI AL-QUDAH}

\section{Associate Professor, College of Law and Political Science, King Saud University. Riyadh, Kingdom of Saudi Arabia, Email: maalqudah@ksu.edu.sa, maen.alqudah@yahoo.com}

Key Words: The Saudi Bankruptcy Law, Settlement procedure, Small Debtors, Debtor's authorities, creditors, debts, Bankruptcy Commission, Small and Medium Enterprise General Authority, Financial turmoil

\begin{abstract}
:
The Saudi Bankruptcy Law states several procedures under the article 2. The Small Debtor's Protective Settlement is one of the essential Bankruptcy's procedures. In this context, article 127 of this law determines the goal of the protective settlement procedure for small a debtor which permits small debtors to achieve an agreement with creditors to resolve the debts during a reasonable time throughout easy, efficient, and inexpensive procedures, allowing the debtor to carry on running of his business.

The Small Debtor's Protective Settlement procedure poses many questions which will be discussed in this study: what is the concept of the Small Debtor's Protective Settlement? What is the importance of this procedure? What are the characteristics of the small debtor's authority privacy in the Small Debtors Protective Settlement Procedure? The key question is that: what is the privacy
\end{abstract}


of the Debtor authorities in the Small Debtors Protective Settlement Procedure according the Saudi Bankruptcy Law 2018?

Accordingly, this study will address the Privacy of the Debtor authorities in the Small Debtors Protective Settlement Procedure under the Saudi Bankruptcy Law 14.02.2018 issued by Royal decree number $(\mathrm{M} / 50)$ dated 14.022018 with reference to its implementing regulations issued by the Ministers Council decision number (622) dated 05.09.2018 in line of the concept of this procedure, its importance, its goal, its characteristics and privacy of the small debtor authorities in this procedure. In conclusion, this study comes out with significant results and recommendations.

\section{Introduction:}

Bankruptcy is the legal procedure by which financially distressed companies and individuals resolve their debts ${ }^{1}$. It is a vital element of the legal environment for small enterprises owners as the small enterprises are extremely risky, unsuccessful. Bankruptcy law influences how enterprises owners are treated in the case of failure. In this regard, individual and company bankruptcy law are related for most small enterprises, even when enterprises are incorporated,

${ }^{1}$ See in details, Repert. G et Roblot. R, Traité élémentaire de Droit Commercial , L.G.D.J, Paris, 1981, p: 609; see also, J. Hamel, G. Lagarde, A. Jauffret, Droit commercial, Dalloz.1980, p:538; Pérochon Françoise et Bonhomme Régine, Entreprises en difficulté et Instruments de Crédit et de Paiement,, 6 edition, L.G.D.Y, Delta, Paris, 2003, P: 4; Fernan Bali, Samir Fernan Bali, Researches in Bankruptcy, Al-Halabi Legal Publications, First Edition 2009, p: 9 and next. 
lenders frequently demand that enterprises owners personally guarantee loans to the business ${ }^{2}$.

In addition, the small debtor's protective settlement is an important procedure according the Saudi Bankruptcy Law 2018. This Law takes in its consideration the difference between the big debtor and the small debtor. In addition, this Law distinguishes in its procedures the nature of the activities, the status of debtors and creditors, the debts amount, as well as the volume of the business activity. Accordingly, this law's procedures are graded from the easy to hard ${ }^{3}$.

Furthermore, this Law provides privacy to the small business. One of the solutions that solve the economic problem for small debtors is the protective settlement of small debtors. In this sense, due to the important role of the small and medium projects in the economical development ${ }^{4}$, this law individualizes the chapter six

\footnotetext{
${ }^{2}$ See in details, Ronald J. Mann, Charging Ahead: The Growth and Regulation of Payment Card Markets Around the World, Cambridge University Press 2006, See also the same sense, Saeed Albostani, Business Law and Companies, Dar Alhalbi, Lebanon, 2004, p:188
}

${ }^{3}$ According to the article 2 of the Saudi Bankruptcy Law, there are seven procedures as following: Protective Settlement, Financial Restructuring, Liquidation, Small Debtor's Protective Settlement, Small Debtor's Financial Restructuring, Small Debtor's Liquidation and administrative liquidation procedure ${ }^{4}$ See in more details, Bayan Harb, The role of small and medium enterprises in economic and social development, Damascus University Journal of Economic and Legal Sciences, Volume, 22, 2ed edition, 2006, p: 111 and next. 
to the Small Debtor's Protective Settlement, the articles from 127 to 141 .

Hence, the aim of this study is to focus on the privacy of the small debtor authorities in the small debtors protective settlement procedure according to the Saudi Bankruptcy Law 2018 issued by Royal decree number (M/50) dated 14.022018 with reference occasionally to its implementing regulations issued by Ministers Council decision number (622) dated 05.09.2018 regarding the concept of this procedure, its importance, its goal, its characteristics and privacy of the debtor authorities in this procedure.

\section{RESEARCH OBJECTIVES AND IMPORTANCE:}

The objective of this study is to address the Privacy of the Debtor authorities in the Small Debtors Protective Settlement Procedure according to the Saudi Bankruptcy Law 2018. This study will also discuss the concept of this procedure, its importance, its goal, and its characteristics.

The importance of this study appears from the essential role of small and medium enterprises in economic development in the Kingdom of Saudi Arabia. In addition, the privacy has been given to the small debtor's protective settlement procedure by Bankruptcy Law 2018 throughout individualizing a complete chapter six in this law. In this regard, the Saudi Bankruptcy Law 2018 illustrates the concept of the Small Debtors Protective Settlement Procedure, its goal, its characteristics and the debtor authorities in this procedure which we will address throughout this study. 


\section{RESEARCH PROBLEM:}

The research problem is centered on the main following question: What is the privacy of the debtor's authorities in the Small Debtors Protective Settlement Procedure according to the Saudi Bankruptcy Law 2018? Besides, the research problem comes out from the debtor authorities in the Small Debtors Protective Settlement Procedure as they are in line with the concept of this procedure.

Consequently, the research problem necessitates to address the privacy of the debtor authorities in the Small Debtors Protective Settlement Procedure according to the Saudi Bankruptcy Law issued by Royal decree number (M/50) dated 14.022018 with reference occasionally to its implementing regulations issued by Council of Ministers' decision number (622) dated 05.09.2018.

\section{RESEARCH METHODOLOGY:}

This paper takes into consideration two methodologies, the descriptive and analytical researches. The descriptive research aims to describe the privacy of the debtor authorities in the Small Debtors Protective Settlement Procedure. In addition, this paper relies on the analytical research with the purpose to analyze the provisions of the Saudi bankruptcy Law issued by Royal decree number (M/50) dated 14.022018 with reference occasionally to its implementing regulations issued by Ministers Council decision number (622) dated 05.09.2018 with the intention to discover the privacy of the debtor authorities in the small debtors protective settlement procedure. Thus, the subject of this research article will split into two sections. The first section is the Concept and importance the Small Debtors Protective Settlement Procedure 
under the Saudi bankruptcy Law under the Saudi bankruptcy Law. The second section is the characteristics of the debtor's authority privacy in the Small Debtors Protective Settlement Procedure under the Saudi bankruptcy Law.

\section{Section 1: Concept and importance of the Small Debtors Protective Settlement Procedure under the Saudi bankruptcy Law}

The Saudi Bankruptcy Law 2018 dealt with the Small Debtors Protective Settlement Procedure. This section will address the definition and the importance of the Small Debtors Protective Settlement Procedure under the Saudi bankruptcy Law as following:

\section{A. The Small Debtors Protective Settlement Procedure definition under the Saudi bankruptcy Law}

The first article of the bankruptcy Law determines the definition of the small debtor. In this sense, the small debtor is a debtor who fulfills the conditions and criteria lay down by the Bankruptcy Committee based on the Small and Medium Enterprises General Authority ${ }^{5}$. Hence, the Bankruptcy Committee should collaborate with the Medium Enterprises General Authority in order to define the small debtor. In addition, under the Bankruptcy Committee decision Number (0218/12) dated 09/11/2018, the small debtor, according the Bankruptcy Law and Implementing Regulations, is

5 Article 1 of this Law disposes that "A debtor who meets the criteria set by the Bankruptcy Committee in coordination with the Small and Medium Enterprises General Authority'. 
one whose debt does not exceed two million Saudi Riyals when Bankruptcy procedures take place.

Accordingly, the debtor will not benefit from the Procedure concerning the Small Debtors Protective Settlement when his debt exceeds two million Saudi Riyals. It should be noted that the Bankruptcy Law gives a priority to the small debtor that seeks to take the Small Debtors Protective Settlement Procedure relying on the debts amount.

Furthermore, the first article of the same law shows the meaning of the Protective Settlement Procedure for small debtors which intends to assist compatibility between the debtor and his creditors to settle his debts, whereas the debtor has the right to continue running his own business ${ }^{6}$. Thus, in the Protective Settlement Procedure for small debtors will not appoint the bankruptcy trustee since the debtor still runs his business ${ }^{7}$.

Moreover, the goal of the Protective Settlement Procedure is to help the debtor find an agreement with his creditors to resolve his debts. In this regard, the previous article confirms that the Protective Settlement Procedure is " A procedure which aims to facilitate an agreement between the debtor and his creditors to

${ }^{6}$ See in the same context, Saeed Albostani, The Provisions of Bankruptcy and Preventive Composition in Arab Legislation, Dar Alhalbi, Lebanon, 2007, p: 73.

${ }^{7}$ The Article 1 of the Bankruptcy Law determines the concept of the Protective Settlement Procedure which status that " A procedure which aims to facilitate an agreement between the debtor and his creditors to settle his debts, where the debtor maintains the right to manage his business". 
settle his debts, where the debtor maintains the right to manage his business. ${ }^{8}$

\section{B. The importance of the Small Debtors Protective Settlement Procedure under the Saudi bankruptcy Law}

The importance of the Small Debtors Protective Settlement Procedure comes as it's a proactive step from the debtor towards his creditors in order to reach an agreement with them to settle his debts. In addition, the Saudi bankruptcy law allocated a full chapter to treat the small debtors 9 .

Besides, the above mentioned procedure helps the debtor to keep managing his business, ${ }^{10}$ gives him the opportunity to correct his situation ${ }^{11}$ with his creditors by protecting him from creditor's claims within a specified period, and increases the debtor's payment rate of his debts without prejudice to the rights of

${ }^{8}$ It's significant to note that this definition is criticized for not addressing the most important feature of this settlement. On other terms, the Protective Settlement Procedure should carry out under the supervision of the judiciary. The impact of this deficiency appears through the confusion between the preventive settlement and a number of settlements that were known under the old law, such as: the administrative settlement which was done through the Chamber of Commerce, and the settlement amicable, or amicable reconciliation.

${ }^{9}$ See chapter six of the Bankruptcy Law (articles 127- 141)

${ }^{10}$ See in the same context, Rashid Fahim, Bankruptcy and Preventive Composition, Technical Office for Legal Issues $1^{\text {st }}$ edition, 2000, p:219 and next.

${ }^{11}$ See in the same sense, Ziad Subhi Dyab, Companies Bankruptcy of in Al-shari'a Al-islamia and law, Dar Alnafaes for publication and distribution, 2011, p:97. 
creditors. ${ }^{12}$ In addition, it motivates the creditors to participate effectively in the procedures and vote on suggested solutions from the debtors.

Furthermore, countries are interested in small and medium enterprises because they are very important to support the national economy. In this sense, the small and medium enterprises are essential in supporting the economical development of the country.

Moreover, small and medium enterprises are considered as one of the economic sectors that occupy an important place in most countries. It's essential to note that the small and medium enterprises are suitable for people with limited income especially these enterprises captures the youth's interest. In addition, these enterprises are considered as an easy way to execute and begin without complex and lengthy procedures. It is normal that some enterprises start with small branch, capital, and small number of workers and grow to become with several branches, and big budgets. Consequently, small and medium enterprises have a major role to boost the economy of countries ${ }^{13}$.

In this sense, the small and medium enterprises present many positive advantages as the following: They provides inexpensive goods cost, they work to meet the citizens' needs in terms of

${ }^{12}$ Mostafa Kamal Taha, Principles of Commercial Law, Commercial Papers and Bankruptcy, Alhahlabi for Publishing, Lebanon, 2012, p:587.

${ }^{13}$ See in the same context, Basma M. Kadhem, International Bankruptcy and the Protection of Creditors Rights, A comparative study, Elmiah Dawkiah for publishing and distribuation, 2017, p: 13 and next. 
products and commodities that may not be found in the markets nearby, it creates job opportunities for the younger generation ${ }^{14}$, it works to reduce pressure on government jobs, it opens many areas of investment which considerably develop the efforts and experiences of younger generation at work, small enterprises are working to improve the productive movement in the country, and increase exports.

It can be deduced from the above the importance of the small and mediums enterprises in several aspects. This importance appears in the founding special rules for small debtors of their bankruptcy as their private capital is intertwined with their own money, and most of the time they depend on credit loans or real estate mortgages to finance their business. In addition, small debtor's enterprises are often individual foundation, persons companies which means that their responsibility is personal with all their money; unlike the joint-stock companies where the partner's responsibility should be within the limits of their shares. Therefore, small enterprises owners are divided to two types of bankruptcy: corporate bankruptcy in relation to their companies, and bankruptcy of persons in relation to themselves. Moreover, the problem imposes when the lenders ask the owners of small and medium enterprises to guarantee loans for their enterprises, or when these enterprises

${ }^{14}$ See in details, David S. Evans and Linda S. Leighton, Some Empirical Aspects of Entrepreneurship, The American Economic Review, Vol. 79, No. 3 (Jun., 1989), pp. 519-535. 
are stressed; it will be difficult for them when the normal bankruptcy procedures are applied. ${ }^{15}$

\section{Section 2: The characteristics of the small debtor authority's privacy in the Small Debtors Protective Settlement Procedure}

The Saudi bankruptcy law takes into consideration the position's privacy of the small debtor. This section will focus on the characteristics of the debtor's authority privacy in the Small Debtors Protective Settlement Procedure as following:

\section{A. Giving the small debtor the right to take the decision of opening the procedure}

Bankruptcy Law gives the small debtor the authority to choose between the opening of the protective settlement procedure and protective settlement procedure for small debtors. In other word, the small debtor could file a demand for the opening of a protective settlement procedure as a replacement of opening the protective settlement procedure for small debtors. In this context, the article $128 / 1$ of Bankruptcy law status that 'the small debtor may file a petition for the initiation of a protective settlement procedure instead of initiating the protective settlement procedure for small debtors".

It can be assumed from the previous article that the debtor has the right to select and to benefit from the easy procedure of the

${ }^{15}$ See in more detail, Michelle J. White, UCSD and NBER, "Small Business Bankruptcy," Annual Review of Financial Economics, volume 8, 2016, pp 317-336. 
protective settlement for small debtors or to proceed with the normal procedure of the protective settlement procedure. In this sense, the Bankruptcy Law determines the goal of the protective settlement for small debtors which authorize small debtors to attain an accord with his creditors to settle the debts within a reasonable time throughout simple, efficient, and inexpensive procedures, permitting the debtor to keep on running his business. ${ }^{16}$ In this regards, it is recommended that the article 127 of the Bankruptcy Law should be changed throughout the determination the concept of 'a reasonable period'.

Furthermore, the Bankruptcy Law allows the small debtor taking the decision to open the procedure of the protective settlement for small debtors without obliging him to submit a petition to the commercial court. In principal, this law makes the decision of opening this procedure up to the debtor under the form issued by the Bankruptcy Commission. Additionally, the debtor's decision should meet with the following conditions:

1. The small debtor is distressed or bankrupt ${ }^{17}$. In this sense the first article of the Bankruptcy Law determines the concept of the distressed as a "debtor who stopped paying a due debt on its maturity date", and the Bankrupt as "'a debtor whose debts have consumed all of his assets".

${ }^{16}$ Article127 of the Bankruptcy Law disposes that " The protective settlement procedure for small debtors aims to enable small debtors to reach an agreement with creditors to settle the debts within a reasonable time through simple, efficient, and low-cost procedures, allowing the debtor to continue management of his business".

${ }^{17}$ See article 129/1 of the Bankruptcy Law. 
2. The small debtor is likely to suffer financial difficulties that may lead to distress ${ }^{18}$. In this regard, the Bankruptcy law did not specify the meaning of the financial turmoil. However, it can be said the financial turmoil means that the debtor's financial position has reached a stage of financial hardship if he continues, it will lead to stop paying his debts, and this stage is prior to stopping payment of debts ${ }^{19}$. The Bankruptcy law did not set specific criteria to distinguish the financial distribution that is entitled. It is recommended that the Bankruptcy law offers a determination for the concept of terms "financial turmoil" and its criteria.

The debtor has the right to request a protective settlement, which means that the evaluation of this issue is in accordance of the judiciary, which needs a lot of good judgment, to distinguish between what is considered as financial turmoil or not considered.

3. The debtor prevents from resorting to begin a protective settlement procedure for small debtors if he has previously been subject to such procedure or to a protective settlement procedure during the preceding 12 months ${ }^{20}$.

${ }^{18}$ See article 129/1 of the Bankruptcy Law; see also, Lamine Dobassy, Les garanties de paiement des créanciers dans les procédures collectives OHADA, LGDJ, Vol 11 paris 2017, p: 653; Aziz Al-Uqaili, Bankruptcy Provisions and Protective Compromise, Dar Al-Thaqafa, Jordan, 1997, p: 323 onwards. .

${ }^{19}$ See in more details, Abdul Hamid al-Dasti Abdul Hamid Shalabi, Financial turmoil in the New Saudi Bankruptcy (analytical Study), Journal of Islamic Studies and Academic Research, Faculty of Dar Al Uloom - Cairo University, volume 15, edition 97, 2020, p:155 and 156. ${ }^{20}$ See article $128 / 2$ of the Bankruptcy Law 


\section{B. the small debtor should prepare the settlement's proposal and has the right of Postponement of the creditors' claims}

The Bankruptcy Law requests that the small debtor shall set the settlement's proposal before taking his decision. This proposal shall contain a short explanation of his financial position and the specified documents by the Implements Regulations. In this context, the article 129/2 of this law disposes that" The small debtor shall, prior to issuing his decision, prepare the proposal which shall include a brief description of his financial position along with the documents specified by the Regulations"'. It is notable that this proposal is final when it obtains the required majority of the creditors' votes ${ }^{21}$ and the creditors vote on it as one class.

In addition, the small debtor shall deposit the opening decision for the commencement of the procedure in the bankruptcy register with a copy of the settlement proposal, and this decision shall take effect from the date of the deposition in the register ${ }^{22}$. In this

${ }^{21}$ See in same sense, Mustafa Kamal Taha and Shareef Mustafa Kamal, Bankruptcy's Principles, The national center for legal publication, 2018, p:276; see also Fayez Naim Radwan, Bankruptcy according the U.A.E, Brighter Horizon Publishers, 2013, p: 247; see also, Elias Nassif, The Complete in the Commercial Law, Awidatt for printing and publishing, $4^{\text {th }}$ part, Lebanon, 1999, p:520.

${ }^{22}$ See article 129/3 of the Bankruptcy Law; see also, Abdul Majeed Saleh Al-Mansour, Jurisprudential Adaptation of the New Bankruptcy Project Procedures, Imam Mohammad Ibn Saud Islamic University, 1438H, P: 36 and next. 
regards, the article 18/1 of the Implement Regulations confirms that in order to inform the third party of the opening the procedure " The debtor shall, upon initiating any protective settlement or financial restructuring procedures, include the type of the initiated procedure in any document issued in his name, and the trustee shall verify the debtor's compliance with the financial restructuring procedures'".

Concerning the right of the small debtor of Postponement creditors' claims $^{23}$, the Bankruptcy Law permits the small debtor to submit the petition for the moratorium to the commercial court. This petition should be filed by using the Bankruptcy Committee form, with a brief summary of the proposal and the requirements specified by the Regulations ${ }^{24}$. It can be concluded that the commercial court does not get involved in the Small Debtors Protective Settlement procedure except if the debtor is requesting the Postponement creditors' claims.

Besides, the commercial court could demand from the small debtor to supply any supporting documents for his petition, counting a

${ }^{23}$ See in more details, Mohammed Mostafa Abdusadek, Commercial Papers and Bankruptcy in Arab Legislation, Dar Alfikr, 2011, p: 397

${ }^{24}$ Article 132/1 of the Bankruptcy Law disposes that " The petition for the moratorium shall be filed with the court using the Bankruptcy Committee form, provided it is accompanied with a brief summary of the proposal and the requirements stipulated by the Regulations". Article 59 of the Implements Regulations confirms that " the small debtor's petition for moratorium shall be accompanied with supporting information and documents'. 
report from his auditor or from a listed trustee or expert indicating the probability of creditors approving the proposal ${ }^{25}$.

Conclusion: This paper discussed the Privacy of the Debtor authorities in the Small Debtors Protective Settlement Procedure according the Saudi Bankruptcy Law 2018.In conclusion, this article came out with some results and recommendations

\section{Firstly: Results}

1. The Small Debtor's Protective Settlement is a significant procedure under the Saudi Bankruptcy Law 2018 as it's a proactive step from the debtor towards his creditors in order to reach an agreement to settle his debts.

2. The Bankruptcy Law gives privacy to the Small Debtor's throughout the allocation a specific procedure for the Small Debtor's Protective Settlement. This Law distinguishes between the procedures of a big debtor and a small debtor.

3. The purpose of the Small Debtor's protective settlement procedure allows the small debtors to accomplish an agreement with creditors to resolve the debts during a reasonable time throughout easy, efficient, and low-cost

\footnotetext{
${ }^{25}$ Article $132 / 1$ of the Bankruptcy Law status that " the court may request the small debtor to provide documents supporting his petition, including a statement from his auditor or from a listed trustee or expert indicating the likelihood of creditors approving the proposal'”.
} 
procedures and permitting the debtor to carry on running of his business.

4. The first article of the bankruptcy Law defines the small debtor who fulfills the conditions and standard set by the Bankruptcy Committee based on the Small and Medium Enterprises General Authority. The Bankruptcy Committee added a clarification on the meaning of the small debtor whose debt does not exceed two million Saudi Riyals when Bankruptcy procedures take place.

5. The Bankruptcy Law allows the small debtor taking the decision to open the procedure of the protective settlement for small debtors without obliging him to submit a petition to the commercial court.

6. Creditors in the Small Debtors' Protective Settlement procedure vote as one class.

7. In a Small Debtors Protective Settlement procedure, the proposal is final when it obtains the required majority of the creditors' votes.

8. The Small Debtor has the right to request the opening of the Protective Settlement Procedure in place of the opening of the Protective Settlement Procedure for Small Debtors.

9. The Bankruptcy Law did not specify the meaning of the financial turmoil. The evaluation of the financial turmoil is in accordance of the judiciary, which needs a lot of good judgment, to distinguish between what is considered as financial turmoil or not considered.

10. The Bankruptcy law did not set specific criteria to distinguish the financial turmoil.

11. The debtor could not commence a protective settlement procedure for small debtors if he has previously been subject 
to such procedure or to a protective settlement procedure during the preceding 12 months.

12. The commercial court does not involve in the Small Debtors Protective Settlement procedure except if the debtor is requesting the petition for the moratorium creditors' claims.

\section{Secondly: Recommendations}

1. It is recommended that the Bankruptcy Committee conducts periodic reviews of meaning and criteria of the small debtor whose debt does not exceed two million Saudi Riyals in accordance with article $9 / 2 /$ o of the Bankruptcy Law.

2. It is recommended that the article 127 of the Bankruptcy Law should be changed throughout the determination the concept of 'a reasonable period" to avoid ambiguity.

3 . It is recommended that the article 127 determines clearly the criteria and aspect of the 'efficient'.

4. It is recommended to change the article 129/1 throughout giving a determination for the terms 'financial turmoil"' to prevent lack of clarity.

5. It is recommended that the article 129 /specify a criteria for the terms 'financial turmoil'.

6. It is recommended that the period of 12 months, under article $128 / 3$, should be reduce to six months in order to stabilize the legal situation. 
7. It is recommended that the period of 90 days, under article $131 / 1$, should be decrease to 60 days in order to guarantee the seriousness of the debtor

8. It is recommended that the Saudi legislator should create a special court for bankruptcy cases, due to the multiplicity and specificity of bankruptcy procedures.

\section{References:}

- Abdul Hamid al-Dasti Abdul Hamid Shalabi, Financial turmoil in the New Saudi Bankruptcy (analytical Study), Journal of Islamic Studies and Academic Research, Faculty of Dar Al Uloom - Cairo University, volume 1

- Abdul Majeed Saleh Al-Mansour, Jurisprudential Adaptation of the New Bankruptcy Project Procedures, Imam Mohammad Ibn Saud Islamic University, 1438H 5, edition 97, 2020.

-Aziz Al-Uqaili, Bankruptcy Provisions and Protective Compromise, Dar Al-Thaqafa, Jordan, 1997.

-Basma M. Kadhem, International Bankruptcy and the Protection of Creditors Rights, A comparative study, Elmiah Dawkiah for publishing and distribuation, 2017.

-Bayan Harb, The role of small and medium enterprises in economic and social development, Damascus University Journal of Economic and Legal Sciences, Volume, 22, 2ed edition, 2006.

-David S. Evans and Linda S. Leighton, Some Empirical Aspects of Entrepreneurship, The American Economic Review, Vol. 79, No. 3 (Jun., 1989), pp. 519-535 
- Elias Nassif, The Complete in the Commercial Law, Awidatt for printing and publishing, $4^{\text {th }}$ part, Lebanon, 1999.

-Fayez Naim Radwan, Bankruptcy according the U.A.E, Brighter Horizon Publishers, 2013.

-Fernan Bali and Samir Fernan Bali, Researches in Bankruptcy, Al-Halabi Legal Publications, First Edition 2009.

-Implementing regulations of the Saudi Bankruptcy Law issued by the Ministers Council decision number (622) dated 05.09.2018

-J. Hamel, G. Lagarde, A. Jauffret, Droit commercial, Dalloz. 1980.

-Lamine Dobassy, Les garanties de paiement des créanciers dans les procédures collectives OHADA, LGDJ, Vol 11 paris 2017.

-Michelle J. White, UCSD and NBER, "Small Business Bankruptcy," Annual Review of Financial Economics, volume 8, 2016.

-Mohammed Mostafa Abdusadek, Commercial Papers and Bankruptcy in Arab Legislation, Dar Alfikr, 2011

-Mostafa Kamal Taha, Principles of Commercial Law, Commercial Papers and Bankruptcy, Alhahlabi for Publishing, Lebanon, 2012.

-Mustafa Kamal Taha and Shareef Mustafa Kamal, Bankruptcy's Principles, The national center for legal publication, 2018. 
-Pérochon Françoise et Bonhomme Régine, Entreprises en difficulté et Instruments de Crédit et de Paiement,, 6 edition, L.G.D.Y, Delta, Paris, 2003.

-Rashid Fahim, Bankruptcy and Preventive Composition, Technical Office for Legal Issues $1^{\text {st }}$ edition, 2000.

- Repert. G et Roblot. R, Traité élémentaire de Droit Commercial, L.G.D.J, Paris, 1981.

-Ronald J. Mann,Charging Ahead: The Growth and Regulation of Payment Card Markets Around the World, Cambridge University Press 2006.

-Saeed Albostani, The Provisions of Bankruptcy and Preventive Composition in Arab Legislation, Dar Alhalbi, Lebanon, 2007.

-Saeed Albostani, Business Law and Companies, Dar Alhalbi, Lebanon, 2004.

-Saudi Bankruptcy Law 14.02.2018 issued by Royal decree number $(\mathrm{M} / 50)$ dated 14.022018

-Ziad Subhi Dyab, Companies Bankruptcy of in Al-shari'a Alislamia and law, Dar Alnafaes for publication and distribution, 2011. 